\title{
BRYOPHYTE RECORDS FROM THE UDZUNGWA SCARP NATURE FOREST RESERVE, TANZANIA
}

\author{
Tamás Pócs \\ Institute of Biology, Eszterházy Károly University, Eger, Pf. 43, Hungary, H-3301; \\ E-mail: colura@upcmail.hu
}

\begin{abstract}
Christian Frimodt-Møller in 1997 collected an interesting bryophyte material in the Tanzanian Udzungwa Mountains, part of the Crystalline Eastern Arc. The material came from the Udzungwa Scarp Forest Reserve, an outsider satellite of the Udzungwa Mountains National Park, which is a bryologically completely unknown part of the south-western end of the mountains. The study site is located in a lower montane rainforest at an elevation of 1500-1700 m. These records fill a gap between the much better known north-eastern part of the Udzungwe Mountains and the Southern Highlands of Tanzania. Altogether 25 species of liverwort and five mosses were identified that in greater part are new to these mountains.
\end{abstract}

Keywords: Crystalline Eastern Arc, endemics, East Africa, Udzungwa Mountains

\section{INTRODUCTION}

The Udzungwa Mountains form the south-western end of the chain of the Crystalline Eastern Arc mountains extending from southern Kenya throughout eastern Tanzania and ending at the Makumbako Gap, which separates it from the Kipengere and Livingstone ranges in the Southern Highland (Figure 1). This mountain range has very old origin (Precambrian granitic and gneissic bedrocks) and continually favourable climatic conditions since its uplift 30 million years ago. It enjoys adequate rainfall throughout the year on the eastern, seaside slopes which are exposed to the rain carrying winds from the Indian Ocean. Therefore the Eastern Arc mountains on their windward side, ridges and high plateaux carry very luxurious rainforest vegetation. As a consequence, these rainforests are very rich both in plant and animal endemics and in elements common with Madagascar and other East African Indian Ocean 
islands (Pócs 1975, 1998, 1999, Burgess et al. 2007). This is in contrast to the much younger volcanic mountains located in drier areas located farther inland from the ocean. At the same time their lee side gets much less rainfall and, accordingly, it is covered by more xerotolerant vegetation, including dry forests and miombo woodland. This asymmetry can be observed in almost all mountains of the Eastern Arc (Pócs 1977). By the time of climatic fluctuations, for example during the Pleistocene, the ratio between the two types of vegetation could drastically change, but the higher slopes and summits were permanently covered by rainforests, at least in some core areas, like the Eastern Arc mountains (Hamilton 1982). The fluctuation of altitudinal belts resulted in repeated isolation of montane forest patches, promoting evolution of endemic species.

By the kindness of Christian Frimodt-Møller, that time botanist of University of Copenhagen (later becoming a tour operator and managing director of a travel agency in Colombia), I received a small collection of bryophytes for identification which he made in December 1997 in the Udzungwa Scarp Forest Reserve at the south-western end of the Crystalline Eastern Arc Mountains in Tanzania (Figure 2). The forest reserve, although not part of the Udzungwa Mountains National Park, enjoys special protection, as its outsider satellite, with a forest covering an area of 20,220 ha. This remote place hitherto was bryologically unknown, therefore a greatest part of the records are new to the mountains. FrimodtMøller collected the bryophytes at one locality. All specimens were gathered at the site bearing according to the collector the following locality data: UDZUNGWA Mountains in Iringa District. Udzungwa Scarp Nature Forest Reserve. On steep E slopes at 1500-1700 m alt. $8^{\circ} 21^{\prime} \mathrm{S}, 35^{\circ} 58^{\prime} \mathrm{E}$. Rainforest dominated by Parinari excelsa, Syzygium sp., Myryanthus holstii and Ficalhoa laurifolia.

The specimens were collected on various substrates, as indicated in the list below. The collecting numbers were given by Frimodt-Møller, the letters after the numbers indicate species segregated from a single gathering. One sample of each number went to the moss herbarium of Copenhagen University (C), while a fully identified set is deposited in the Herbarium of Eszterházy Károly University, Eger, (EGR). The nomenclature in most cases follows Wigginton (2018) and O'Shea (2006), apart from the names used in more recent revisions. Global distributional data are given 
for each species and for some species names some heterotypic and homotypic synonyms are provided.

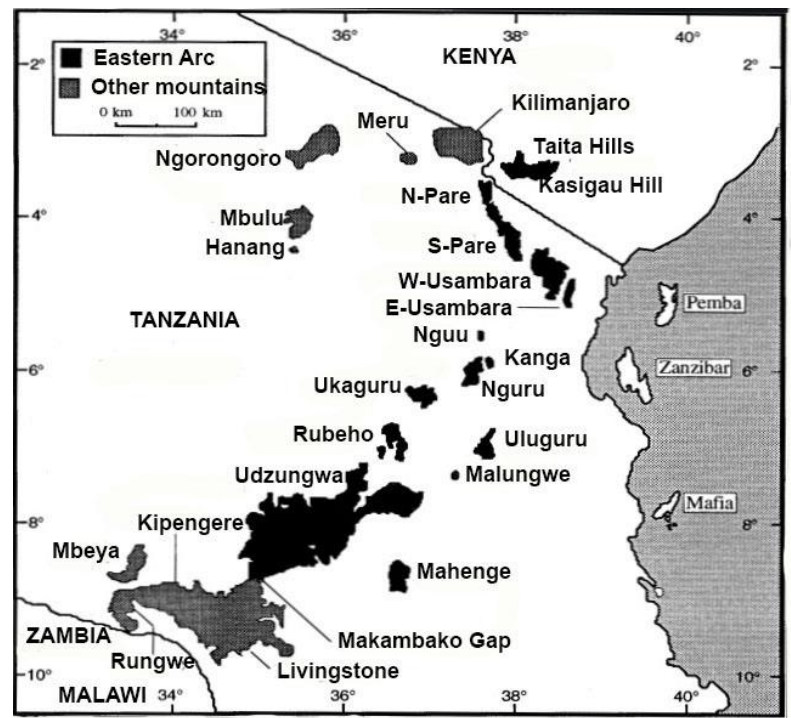

Figure 1. The Crystalline Eastern Arc mountain range from southern Kenya to southern Tanzania (Black. Other, mostly volcanic mountains are marked by grey color. After Burgess et al. 2007).

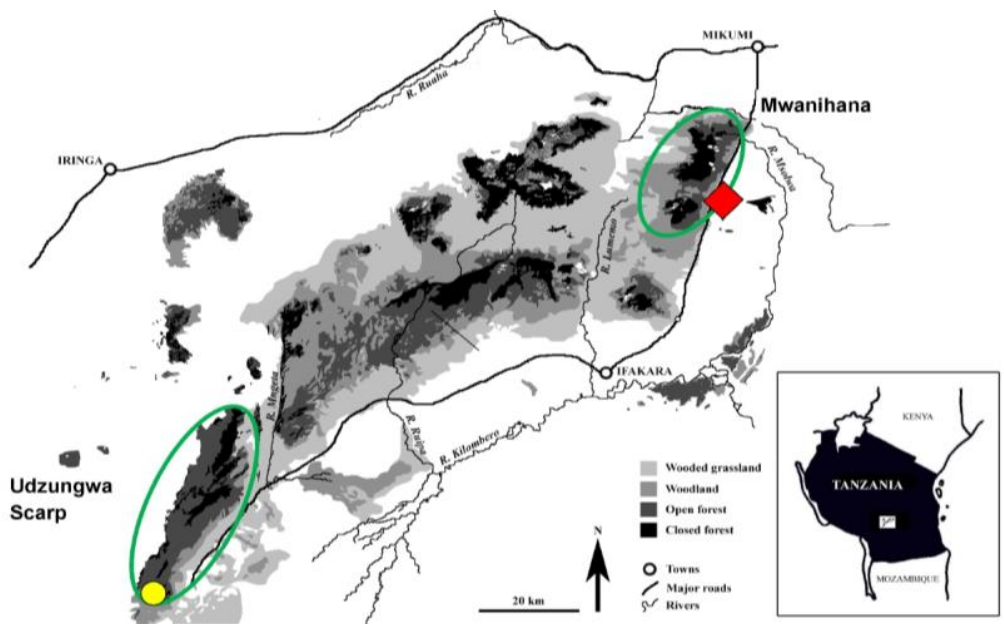

Figure 2. The Uzungwe Mountains. The bryophytes of northeastern part (Mwanihana Forest reserve within the National Park area, marked by diamond) are relatively well known, while the Udzungwe Scarp Forest Reserve at the southwestern end (area marked by light dot) was bryologically unknown (Map after Enghoff 2016). 


\section{RESULTS}

\section{List of species}

Liverworts

Acrobolbus limbatus (Steph.) Briscoe \& J.J.Engel (Figure 5) - On decaying wood. TZ634/A. Syn.: Marsupidium limbatum (Steph.) Grolle, Tylimanthus limbatus Steph. A southern temperate AfroAmerican disjunct (Gradstein et al. 1984), very rare in Africa, hitherto known from the Cape, Malawi, Tanzania (Kilimanjaro), and from the Mascarene Islands: Mauritius and Réunion (Wigginton 2018).

Bazzania decrescens (Lehm. \& Lindenb.) Trev. - On decaying log. TZ710/A. A widespread Afromontane species, closely related to the Australasian Bazzania adnexa (Lehm. \& Lindenb.) Trevis (Jones 1975).

Ceratolejeunea cornuta (Lindenb.) Steph. - On twigs. TZ649/D. A widespread tropical Afro-American or pantropical species, the African representatives used to be named as Ceratolejeunea calabariensis Steph. (Pócs 2011).

Cheilolejeunea trapezia (Nees) Kachroo \& R.M.Schust. - On twigs. TZ636/B. A widespread palaeotropical species, common in Africa.

Cololejeunea malanjae Steph. (Figure 6) - Epiphyllous. TZ708/L. A southeast tropical African species distributed from the Democratic Republic of Congo and Kenya to Malawi.

Cololejeunea microscopica (Taylor) A.Evans - Epiphyllous. TZ708/P. A very variable pantropical species penetrating in the oceanic parts of the temperate regions.

Cololejeunea tanzaniae Pócs (Figure 7) - Epiphyllous. TZ708/D An East African endemic distributed from Kenya and Tanzania to the Indian Ocean islands (Pócs 1980).

Cololejeunea zenkeri Steph. Syn.: Cololejeunea duvigneaudii E.W.Jones - Epiphyllous. TZ708/K. A very widespread epiphyllous species in tropical Africa.

Cryptolophocolea martiana (Sw.) L.Söderstr. \& Váňa - On decaying log. TZ710/C. A widespread tropical Afro-American species (see map in Gradstein et al. 1984). 
Diplasiolejeunea zakiae Tixier (Figure 8) - Epiphyllous. TZ708/H. A rare endemic species of East Africa known only from Kenya, Tanzania and Madagascar (Tixier 1977, Bizot and Pócs 1974, 1982, Pócs and Geissler 2002). In Tanzania it was previously known only from the Uluguru Mountains.

Drepanolejeunea cultrella (Mitt.) Steph. - Epiphyllous and among mosses. TZ634/B, TZ708/G \& J, TZ636/A. A very widespread tropical African species.

Drepanolejeunea physifolia (Gottsche) Pearson - Epiphyllous. TZ708/C. A widespread tropical African species closely related or identical to the palaeotropical Drepanolejeunea vesiculosa (Mitt.) Steph.

Drepanolejeunea pocsii Grolle (Figure 9) - Epiphyllous. TZ708/M. An East African endemic known from Kenya, Tanzania, Malawi, Zimbabwe and from the Indian Ocean islands (Grolle 1976, Wigginton 2018).

Frullania serrata Gottsche - On bark. TZ713. A widespread palaeotropical species, common in tropical African mountains above 900 m elevation (Vanden Berghen 1976).

Lejeunea acuta Mitt. - Epiphyllous and ramicolous. TZ634/A, TZ708/A. Widespread in tropical African mountains (Vanden Berghen 1961, under Hygrolejeunea acuta).

Lejeunea flava (Sw.) Nees - Epiphyllous. TZ636/B. A common pantropical species.

Lejeunea grossecristata (Steph.) E.W.Jones - Epiphyllous. TZ708/B. A taxon of dubious status belonging to the Lejeunea flava complex, namely to Lejeunea tabularis (Spreng.) Gottsche, Lindenb. \& Nees (Jones 1979, Pócs 1993). Widespread in tropical Africa.

Marchantia pappeana Lehm. subsp. pappeana (Figure 10) - On ground. TZ642, TZ716. The type subspecies is widespread in tropical Africa, while subsp. robusta (Steph.) Bischl. occurs in India and Sri Lanka (Perold 1999).

Metzgeria consanguinea Schiffn. - On twigs. TZ636/E. A widespread pantropical species occurring in all tropical African mountains.

Metzgeria leptoneura Spruce - On mosses. TZ649/C. A subcosmopolitan species common in the tropics and penetrating 
in the subtropics and the oceanic parts of the temperate zones. Widespread in African mountains.

Microlejeunea africana Steph. - Epiphyllous. TZ708/F, TZ634/C. A tropical African species close to Microlejeunea bullata (Taylor) Steph. and to the boreal temperate Microlejeunea ulicina (Taylor) A.Evans (Jones 1969, Wigginton and Van de Kerckhove 2004).

Plagiochila fusifera Taylor - Epiphyllous. TZ636/C. A widespread tropical African species.

Plagiochila kiaeri Gottsche - On twigs. TZ636/D. A widespread tropical African species.

Plagiochila pectinata (Willd.) Lindenb. - Epiphyllous. TZ708/O. A relatively rare tropical montane species occurring mostly on West and East African islands and in the Cristalline Eastern Arc mountains (Wigginton 2018).

Radula madagascariensis Gottsche - Epiphyllous. TZ708/E. A palaeotropic species, widespread from East Africa to Indonesia and the Philippines. In Africa it is known only from Kenya, Tanzania, Malawi, the Comoro Islands, Madagascar, Réunion and Mauritius (Yamada 1979, Pócs 1992, Wigginton 2018).

Mosses

Leucoloma subsecundifolium Broth. (Figure 4) Syn: L. volkensii Broth. - On bark. TZ648. A South-East African endemic, known from Kenya, Tanzania, Malawi and the Comoro Islands (La Farge 2002b). A typical member of mossy montane cloud forests.

Leucoloma zuluense Broth. \& Bryhn (Figure 3)- On twigs. TZ635. A South-East African endemic, known from Kenya, Tanzania, Zimbabwe and South Africa. Its var. ovatum La Farge occurs also on the Comoro Islands (La Farge 2002a).

Plagiomnium rhynchophorum (Hook.) T.J.Kop. - On ground. TZ715. A palaeotropic species occurring scattered all over tropical Africa and Asia. (O'Shea 2006, Koponen et al. 2019)

Porotrichum elongatum (Welw. \& Duby) Gepp - On twigs. TZ643/A. A very widespread epiphyte all over tropical Africa (O'Shea 2006).

Pyrrhobryum spiniforme (Hedw.) Mitt. - On decaying log. TZ710/B. A common pantropical moss. 


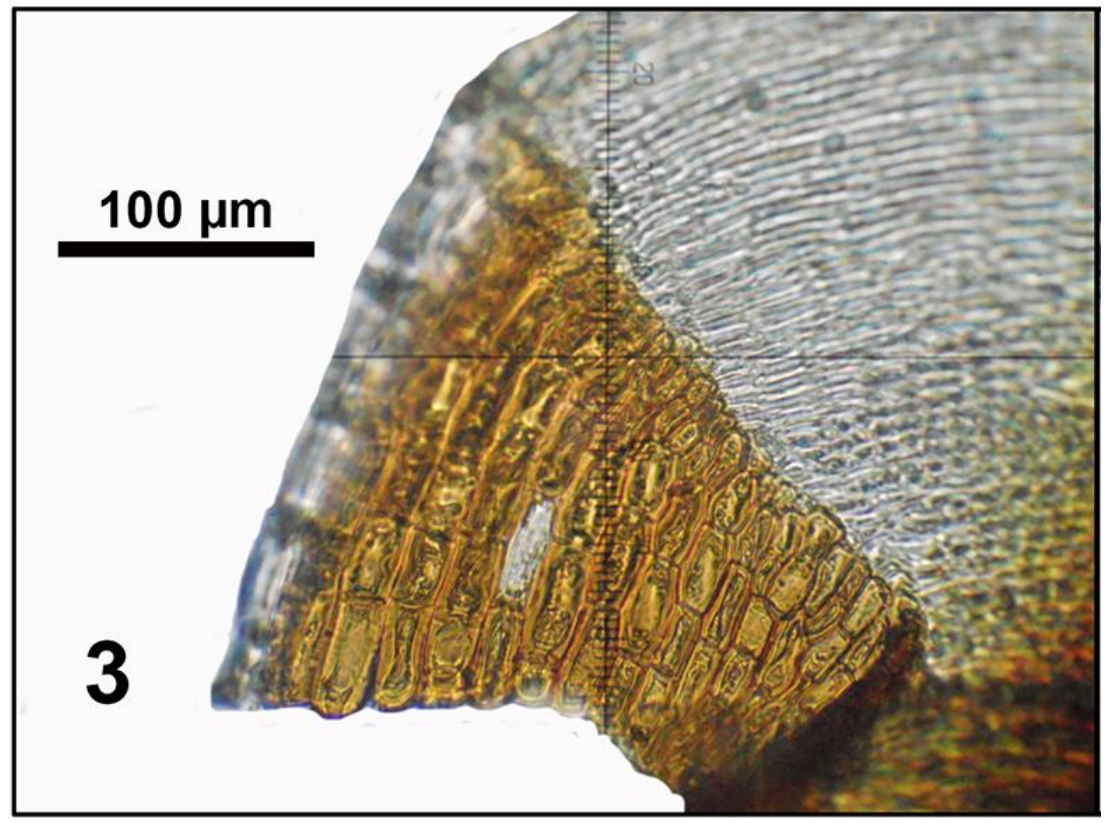

Figure 3. Alar region of Leucoloma zuluense Broth. \& Bryhn (from Frimodt-Møller TZ635).

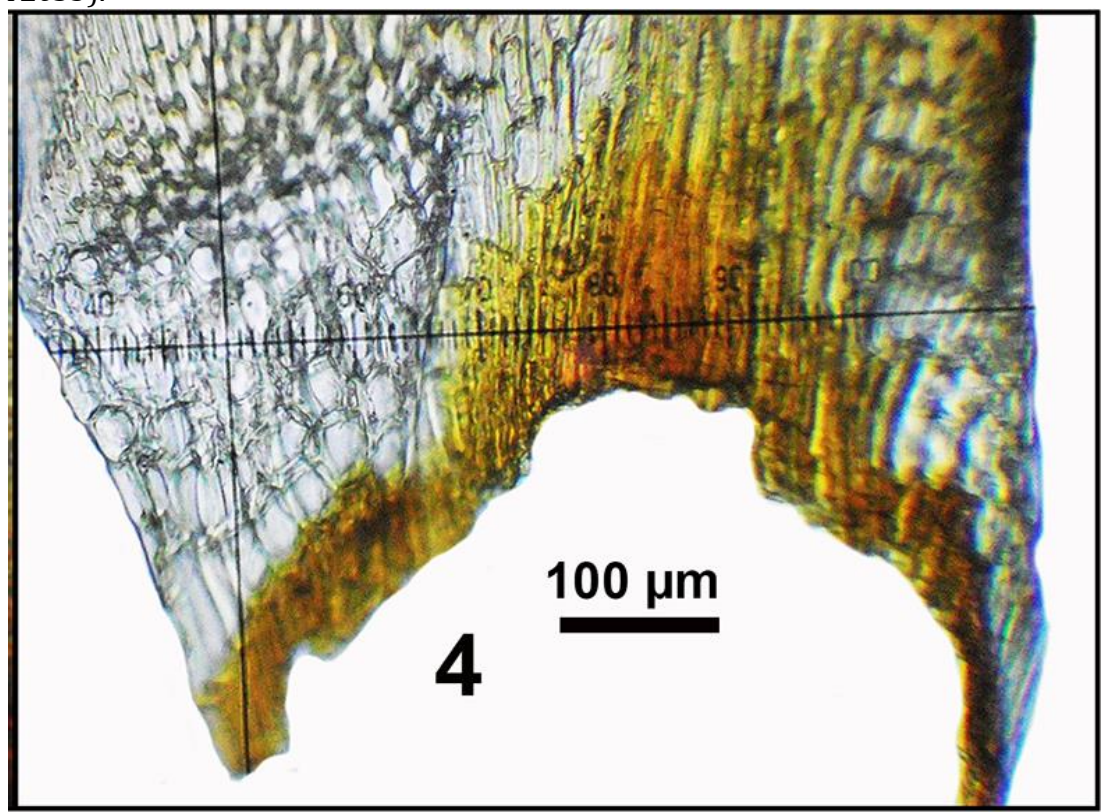

Figure 4. Alar region of Leucoloma subsecundifolium Broth. (from Frimodt-Møller TZ648). 


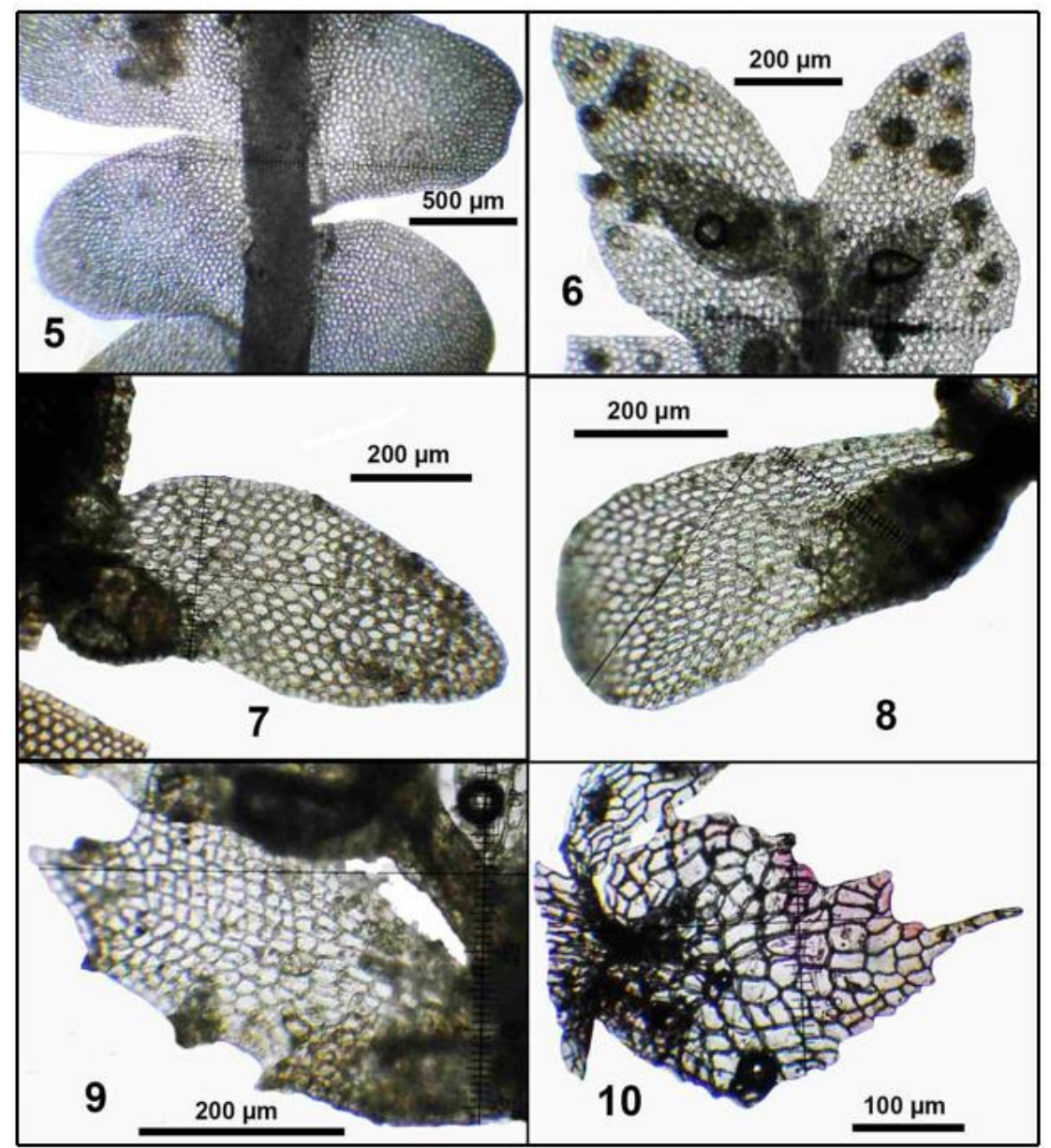

Figure 5. Acrobolbus limbatus (Steph.) Briscoe \& J.J.Engel, habit, ventral view (from Frimodt-Møller TZ634/A). Figure 6. Cololejeunea malanjae Steph., habit, ventral view (from Frimodt-Møller TZ708/L). Figure 7. Cololejeunea tanzaniae Pócs, leaf, ventral view (from Frimodt-Møller TZ708/D). Figure 8. Diplasiolejeunea zakiae Tixier, leaf, ventral view (from Frimodt-Møller TZ708/H). Figure 9. Drepanolejeunea pocsii Grolle, leaf, ventral view (from Frimodt-Møller TZ708/M). Figure 10. Marchantia pappeana Lehm. Appendage of a ventral scale (from Frimodt-Møller TZ642).

\section{DISCUSSION}

The low number of species collected does not permit to draw extensive conclusions concerning the flora element composition of the study area, but even so, the relatively high proportion of 
endemic and subendemic species is conspicuous. Such elements are represented by Cololejeunea malanjae, C. tanzaniae, Diplasiolejeunea zakiae, Drepanolejeunea pocsii, Leucoloma subsecundifolium and L. zuluense, which constitute $20 \%$ of the total number of species. This high level of endemicity is even more striking among the animals. Among mammals, like the Udzungwa red colobus (Cercocebus galeritus), Kipunji (Rungwecebus kipunji) which is among the world's 25 most endangered mammals, the Abbot's duiker (Cephalopuis spadix); among birds the Udzungwa forest partridge (Xenoperdix udzungwensis) and last but not least the highly endangered Udzungwa Scarp tree frog (Nectophrynoides wendyae) which occurs only in one valley of the investigated area (Wikipedia 2019). Of course, the invertebrate fauna contains even higher ratio of endemics, probably thousands of still undescribed species (Enghoff 2016). Regrettably, the forest areas in the Eastern Arc mountains continuously shrivel, partly due to human activities, partly due to the global warming or the combination of the two. This is why the effective protection of these last primary forest covered blocks of the Crystalline Eastern Arc, and especially of the Udzungwe Scarp Forest Reserve would be essential (Seki et al. 2011, Rovero et al. 2005, 2010). Since 2008 the Tanzania Forest Conservation Group, cooperating closely with the Trento Museum of Natural History, Italy, have worked with communities around the reserve to promote awareness of the importance of conservation values.

Acknowledgement - I wish to express my gratitude towards Dr Christian Frimodt-Møller for putting his bryophyte collection at my disposal. Thanks are also due for the information and guidance provided by A.J. Isango and David C. Moyer during my last stay in the Udzungwa Mountains in May 1999. Finally I am grateful to my reviewers, Prof. Ryszard Ochyra and Dr. Andrea Sass-Gyarmati, for their useful corrections and advises.

\section{REFERENCES}

Bizot, M. \& Pócs, T. (1974). East African bryophytes I. Acta Academiae Paedagogicae Agriensis 12: 383-449.

Bizot, M. \& Pócs, T. (1982). East African bryophytes V. Acta Botanica Academiae Scientiarum Hungaricae 28: 15-64.

Burgess, N.D., Butynski, T.M., Cordeiro, N.J., Doggart, N.H., FJeldSA, J., Howell, K.M., Kilahama, F.B., Loader, S.P., Lovett, J.C., Mbilinyi, B., Menegon, M. Moyer, D.C., 
Nashanda, E., Perkin, A., Rovero, F., Stanley, W.T. \& Stuart, S.N. (2007). The biological importance of the Eastern Arc Mountains of Tanzania and Kenya. Biological Conservation 134: 209-231.

https://doi.org/10.1016/j.biocon.2006.08.015

ENGHoff, H. (2016). A mountain of millipedes IV: Species of Prionopetalum Attems, 1909, from the Udzungwa Mountains, Tanzania. With notes on "P." fasciatum (Attems, 1896) and a revised species key (Diplopoda, Spirostreptida, Odontopygidae). European Journal of Taxonomy 215: 1-23. https://doi.org/10.5852/ejt.2016.215

Gradstein, S.R., Pócs, T. \& VÁŇA, J. (1984, „1983”). Disjunct hepaticae in tropical America and Africa. Acta Botanica Hungarica 29: 127-171.

Grolle, R. (1976). Drepanolejeunea subgen. Kolpolejeunea - eine neue Untergattung aus der Paläotropis. Journal of the Hattori Botanical Laboratory 40: 191-216.

Hamilton, A.C. (1982). Environmental history of East Africa. A study of the Quaternary. Academy Press, London \& New York, 328 pp.

Jones, E.W. (1969). African Hepatics XXI. Microlejeunea, Chaetolejeunea and Pleurolejeunea. Transactions of the British Bryological Society 5: 775-789.

JonES, E.W. (1975). African Hepatics XXVII. Bazzania. Journal of Bryology 8: 299316.

JonEs, E.W. (1979). African Hepatics XXXI. Rare or little-known Lejeuneaceae and extensions of range. Journal of Bryology 10: 387-400.

Koponen, T., Nguyen, Th-L., Luong, Th-T. \& Huttunen, S. (2019). Revision and checklist of the moss families Bartramiaceae and Mniaceae in Vietnam. Hattoria 10: 69-107. https://doi.org/10.18968/hattoria.10.0_69

LA FARGE, C. (2002a). Leucoloma II: A revision of Leucoloma series Holomitrioidea (Dicranaceae). Bryologist 105: 591-605. https://doi.org/10.1639/0007-2745(2002)105[0591:LIAROL]2.0.C0;2

LA FARGE, C. (2002b). Leucoloma III: A species synopsis: typification, synonymy and excluded names. Bryologist 105: 606-624.

https://doi.org/10.1639/0007-2745(2002)105[0606:LIASST]2.0.CO;2

O'SHEA, B.J. (2006). Checklist of the mosses of sub-Saharan Africa (version 5, 12/6). Tropical Bryology Research Reports 6: 1-252.

Perold, S.M. (1999). Hepatophyta. Part 1. Marchantiales. Fasc. 1. Marchantiidae, In: LeISTner, O.A. (ed.): Flora of Southern Africa. Pretoria: National Botanical Institute, $252 \mathrm{pp}$.

Pócs, T. (1975). Affinities between the bryoflora of East Africa and Madagascar. In: MiÈGE, J. \& STORK, A. (eds.): Origines des flores africaines et malgaches. Nature, spéciation. Comptes-rendues de la VIIIe réunion de l'AETFAT, 1. Boissiera 24a: $125-128$.

Pócs, T. (1977, "1976”). Bioclimatic studies in the Uluguru Mountains (Tanzania, East Africa) II. Correlations between orography, climate and vegetation. Acta Botanica Academiae Scientiarum Hungaricae 22: 163-183.

Pócs, T. (1980). New or little known epiphyllous liverworts, II. Three new Cololejeunea from East Africa. Journal of the Hattori Botanical Laboratory 48: 305-320.

Pócs, T. (1992) Correlation between the tropical African and Asian bryofloras. II. In: Koponen T. \& Hyvönen, J. (eds.): Proceedings of the Congress of East Asiatic Bryology, Helsinki, August 12-19, 1990. Bryobrothera 1: 35-47. 
Pócs, T. (1993). Taxonomic results of the BRYOTROP expedition to Zaire and Rwanda 12. Metzgeriaceae, Plagiochilaceae, Lejeuneaceae (the non epiphyllous collections). Tropical Bryology 8: 105-125.

Pócs, T. (1998). Bryophyte diversity along the Eastern Arc. Journal of East African Natural History 87: 75-84.

Pócs, T. (1999). Bryophyte speciation and diversity in the East African mountains. Bryobrothera 5: 237-245.

Pócs, T. (2011). East african bryophytes XXIX. The Ceratolejeunea (Lejeuneaceae) species of the Indian Ocean islands. Polish Botanical Journal 56(2): 131-153.

Pócs, T. \& Geissler, P. (2002). Chapter 3. The bryophytes collected in the Réserve Spéciale de Manongarivo, Madagascar. In: Gautier, L. \& Goodman, S.M. (eds.): Inventaire Floristique et Faunistique de la Réserve Spéciale de Manongarivo (NW Madagascar). Boissiera 59: 41-76.

Rovero, F. \& MENEgon, M. (2005). Uzungwa Scarp, an outstanding Eastern Arc forest: biological value and urgent need for protection. In: KeYuU, J., Mduma, S. \& LABORA, A. (eds.): Proceedings of the 5th Tanzania Wildlife Research Institute Scientific Conference, TAWIRI, Arusha, pp. 183-187.

Rovero, F., Mtui, A., Kitegile, A., Nielsen, M. \& Jones T. (2010). Uzungwa Scarp Forest Reserve in crisis. An urgent call to protect one of Tanzania's most important forests. USFR Report, Dar es Salaam, 15 pp.

Seki, H.A., Bowkett, A.E., Bungard, M.J., Doggart, N. \& Menegon, M. (2011). Current status of three endangered hyper-endemic amphibian species in the Uzungwa Scarp Forest Reserve, Tanzania. Tanzania Forest Conservation Group and Whitley Wildlife Conservation Trust, Dar es Salaam, $12 \mathrm{pp}$.

TIXIER, P. (1977). Espèces nouvelles malgaches du genre Diplasiolejeunea (Spruce) Schiffn. (Hepaticae). Lindbergia 4: 117-125.

VAnden Berghen, C. (1961). Hépatiques récoltées par Dr J.-J. Symoens dans la région péri-tanganyikaise. Bulletin de la Société Royale de Botanique de Belgique 93: 55-74.

Vanden Berghen, C. (1976). Frullaniaceae (Hépaticae) Africanae. Bulletin du Jardin Botanique National de Belgique 46: 1-220.

WigginTon, M.J. (2018). Checklist and distribution of the liverworts and hornworts of sub-Saharan Africa, including the East African Islands. Tropical Bryology Research Reports 9: 1-138.

Wigginton, M.J. \& VAN DE Kerckhove, O. (2004). EW Jones's liverwort and hornwort flora of West Africa. National Botanic Garden, Meise, $443 \mathrm{pp}$.

WIKIPEDIA (2019). Udzungwa Mountains. https://en.wikipedia.org/wiki/ Udzungwa Mountains. (Accessed: 28 September 2019)

YAMADA, K. (1979). A revision of Asian taxa of Radula, Hepaticae. Journal of the Hattori Botanical Laboratory 45: 201-322.

(submitted: 26.04.2020, accepted: 14.05.2020) 